\title{
SECOND INTERNATIONAL CONGRESS OF BIOCHEMISTRY
}

T $\mathrm{HE}$ Second International Congress of Biochemistry was held in Paris at the Sorbonne during July $21 \cdots 27$ and was attended by some two thousand two hundred members from all parts of the world, including about four hundred from Great Britain. Although the large number of adherents proved a surprise and even an embarrassment to the organizers, the arrangements worked with a smoothness which revealed a vast amount of careful preliminary organization by the executive committee under the chairmanship of Prof. C. Fromageot, with Prof. J. E. Courtois as general secretary.

The opening session in the grand amphitheatre of the Sorbonne was attended, in the unavoidable absence of the President of the Republic, by the Minister for National Education, who brought the good wishes of the French Government. The meeting was also addressed by Prof. Gabriel Bertrand, honorary president, by Prof. René Fabre, president of the Congress, and by Prof. C. Fromageot.

Four general lectures were delivered to the congress as a whole : by Prof. J. N. Davidson (Great Britain) on "Nucleoproteins and Tissue Growth" (in English), by Academician A. Oparine (U.S.S.R.) on "Les changements de l'action enzymatique dans les cellules végétales sous l'influence des facteurs exterieurs" (in Russian), by Prof. S. Ochoa (United States) on "Fixation of $\mathrm{CO}_{2}$ in Animals and Plants" (in English), and by Prof. K. U. Linderström-Lang (Denmark) on "Protéines et enzymes" (in French). It is proposed to publish these lectures in the near future.

The main part of the Congress was divided into seven symposia running simultaneously, at which the main papers were moderately comprehensive reviews of recent work given by invitation by recognized authorities on the subjects concerned. These symposia have been published and were available in printed form at the beginning of the Congress. The symposia were supplemented by short communications given by members of the Congress at large.

In symposium No. 1, for example, on the "Biochemistry of Hæmopoiesis", H. G. Wijmenga (Holland) and M. S. Shorb (United States) reviewed recent work on the chemistry and microbiological assay respectively of the cobalamins (the vitamin $\mathrm{B}_{12}$ group), while the role of folic acid and the citrovorum factor was dealt with by E. L. R. Stokstad (United States). A most useful review of the metabolism of metals in hæmopoiesis was given by $\mathrm{S}$. Granick (United States), who, as might be expected, dealt chiefly with iron and the importance of ferritin in its absorption and utilization, but who included the parts played by copper, cobalt, molybdenum and zinc. This led naturally to the bone marrow (M. Errera, Belgium) and to the utilization of proteins in blood cell formation (A. Aschkenazy, France). A. Neuberger (Great Britain) surveyed the important recent work on the biogenesis of the hæmin pigments with particular reference to porphyrin formation and the porphyrias, while M. 'F. Perutz (Great Britain) covered the structure of hæmoglobin.

The complex subject of the "Biogenesis of Proteins" was discussed in symposium No. 2. It opened with a masterly account by J. S. Fruton (United States) of peptide bond synthesis, which was followed by a discussion of the molecular kinetics of proteolytic enzymes by $H$. Neurath (United States) and of the role of glutamine, asparagine and glutathione in biosynthesis, by $\mathrm{H}$. Waelsch (United States). The general problem of enzymatic peptide synthesis was dealt with in some detail by H. Borsook (United States), while the more specialized aspects of the formation of specific proteins were discussed by other speakers-milk proteins by T. S. Work (Great Britain), serum proteins and antibodies by $\mathrm{F}$. Haurowitz (United States), procollagens by $V$. N. Oriekhovitch (U.S.S.R.), isohæmagglutinins by R. Wurmser (France), penicillinase by M. R. Pollock (Great Britain) and adaptive enzymes by J. Monod (France). The vexed question of the function of ribonucleic acid in protein synthesis was surveyed by $H$. Chantrenne (Belgium), and the curious phenomenon of long-range enzymatic action by $\mathrm{A}$. Rothen (United States) and by J. Winter (France).

Perhaps the symposium which aroused the greatest general interest was No. 3, on the "Tricarboxylic Acid Cycle". H. A. Krebs (Great Britain) introduced the subject by discussing the place of the cycle in cell metabolism, and was followed by C. Martius (Germany) and S. Ochoa (United States), who concentrated on certain detailed aspects. In such a discussion as this it was natural that coenzyme $\mathrm{A}$ should be dealt with in detail. F. Lipmann (United States) gave a general survey of its importance and discussed in detail recent studies on the synthesis of acetyl-coenzyme $\mathrm{A}$ by way of the interaction of adenosine triphosphate, coenzyme $\mathbf{A}$ and acetate which has led to the discovery of coenzyme A-pyrophosphate. The importance of the cyclophorase system was fully reviewed by D. E. Green (United States). This paper and the following one by $\mathbf{F}$. Leuthardt (Switzerland) emphasized the importance of the mitochondria in the internal economy of the cell both in relation to the process of oxidation and to the formation of urea by the linking of the arginine cycle with the metabolism of glutamate and malate.

The biochemical dissection of some steps in the tricarboxylic acid cycle by means of inhibitors, and in particular its specific inhibition by toxic fluorocompounds, was described by Sir Rudolph Peters (Great Britain), while alternative pathways and variations in the cycle were discussed by E. S. Guzman Barron (United States). No discussion of the citric acid cycle would be complete without reference to its role in fatty acid oxidation, which was ably reviewed by F. L. Breusch (Turkey). The final paper in this symposium was by W. A. Engelhardt (U.S.S.R.) on the enzymology of myosin.

Symposium No. 4, on "Hormones related to Proteins", provided a more miscellaneous collection of material. S. J. Folley (Great Britain) discussed the hormonal control of the initiation and maintenance of lactation with special reference to the adrenal cortex and insulin. The opposing actions of these hormones was illustrated by the observation that the potentiating effect of insulin on lipogenesis from small molecules could be diminished or abolished by cortisone. F. Sanger (Great Britain) reviewed his recent important work on the structure of insulin, for which the complete amino-acid sequences of fractions $A$ and $B$ are now available. norAdrenaline was discussed by U. S. von Euler (Sweden), and the biologically important amines by Z. M. Bacq (Bel- 
gium). The recent work of the Cambridge school on the metabolic influence of the pituitary growth hormone was ably surveyed by F. G. Young (Great Britain). R. Michel (France), in a remarkably thorough survey of the thyroid hormone, discussed the biogenesis of thyroxine, the formation and proteolysis of thyroglobulin and the nature of the circulating hormone.

It was not surprising to find that the fifth symposium, on the "Metabolism of Micro-organisms", was also very varied in content. E. Chargaff (United States) discussed the nucleic acids of micro-organisms, a subject which was also touched on by $D$. D. Woods (Great Britain) in his paper on the formation of folic acid and related growth factors. The surprising versatility of the various active forms of vitamin $B_{a}$ in enzymic reactions was clearly brought out by E. E. Snell (United States), while the lipids of the mycobacteria were reviewed in a comprehensive fashion by E. Lederer (France). Three papers dealt with the formation and metabolism of aromatic compounds. B. E. Davis (United States) and G. Ehrensvärd (Sweden) gave stimulating reviews of the biosynthesis of aromatic rings, and K. G. Stanier (United States) dealt with their oxidation.

The metabolism of micro-organisms featured prominently also in symposium No. 6, on the "Mode of Action of Antibiotics". W. W. Umbreit (United States) explained that streptomycin inhibited a reaction between oxalacetate and pyruvate which is lost in resistant cells. Both E. F. Gale (Great Britain) and F. Gros (France) emphasized the profound changes in nucleic acid metabolism and in protein motabolism (particularly the blocking of the uptake of glutamic acid) which take place in micro-organisms treated with penicillin. Staphylococcus aureus, for example, grown in presence of penicillin, produces derivatives of uridine- 5 '-pyrophosphate which were described by J. T. Park (United States). Discussion of the mode of action of antibiotics led naturally to the question of resistance, the genetic aspects of which were dealt with by L. L. Cavalli (Italy). R. D. Hotchkiss (United States) described how penicillinsensitive rough-strain pneumococci give rise to a proportion of penicillin-resistant variants when grown in the presence of the deoxyribonucleic acid prepared from rough strains selected for spontaneously arising penicillin resistance. Finally, S. Americano-Freire (Brazil) gave an extensive account of the antibiotic properties of $p$-amino salicylic acid and its phenyl ester in experimental tuberculosis.

The seventh and last symposium dealt with "Steroids". The question of the relationship between chemical structure and biological activity was discussed for steroids in general by C. W. Shoppee (Great Britain) and for their 6-hydroxy derivatives by M. R. Ehrenstein (United States). G. Pincus (United States) dealt all too briefly with his recent fascinating work on steroid biosynthesis in the isolated perfused adrenal gland while W. Dirscherl (Germany) surveyed the effects of steroids on enzymatic reactions and metabolic processes. The urinary excretion of steroids and its clinical significance was discussed by E. R. Venning (Canada), G. F. Marrian (Great Britain), L. G. Huis in't Veld (Holland) and M. F. Jayle (France).

It was, of course, clear to the organizers of the Congress that all the original papers submitted by members could not be incorporated into the framework of the seven symposia. Such communications were therefore given in the most appropriate of the thirty-one different sections, which met in the afternoons and covered the following fields of biochemistry: (1) mineral elements ; (2) lipids ; (3) amino-acids and proteins ; (4) nucleoproteins ; (5) pigments ; (6) fatsoluble vitamins; (7) water-soluble vitamins; (8) enzymes and coenzymes; (9) carbohydrases; (10) esterașes; (11) phosphatases and depolymerases; (12) proteases; (3) oxidases and dehydrogenases; (14) carbohydrate metabolism; (15) amino-acid metabolism; (16) sulphur metabolism; (17) fermentations; (18) plant chemistry; (19) plant metabolism; (20) photosynthesis; (21) nutrition; (22) biochemistry of ossification; (23) clinical chemistry; (24) immunochemistry; (25) blood clotting; (26) muscle biochemistry; (27) physiological chemistry and pharmacodynamics; (28) chemotherapy; (29) biochemical effects of ultrasonics; (30) chemistry of cancer; (31) apparatus and techniques.

The lighter side of the Congress involved a large number of social functions, including a special performance of ballet at the Théatre National de l'Opéra and a whole-day excursion to Chantilly and Compiègne.

At the closing session of the Congress, with Prof. Fabre presiding, Prof. J. N. Davidson, who was deputizing for Sir Charles Harington as chairman of the International Committee, announced that an invitation had been received to hold the Third International Congress of Biochemistry in Brussels in 1955. Expressions of appreciation of the work of the French organizers were given formally by Prof. A. Tiselius (Sweden), Sir Rudolph Peters (Great Britain), Academician A. Oparine (U.S.S.R.), Prof. S. Ochoa (United States) and Prof. E. J. Bigwood (Belgium).

\section{SOCIETY FOR APPLIED BACTERIOLOGY}

\section{SUMMER CONFERENCE IN CAMBRIDGE}

THE summer conference of the Society for Applied Bacteriology was held during July 22-24 in Newnham College, Cambridge, and included a symposium, sessions for reading papers and visits to places of interest. At the annual general meeting, Dr. J. G. Davis (London) was elected president for the ensuing two years. The secretary of the Society, from whom further information can be obtained, is G. Sykes, of Boots Pure Drug Co., Ltd., Nottingham.

The symposium, to which contributions were made by $\mathrm{H}$. B. Hawley (Yeovil), M. Ingram (Cambridge), R. S. Hannan (Cambridge), A. Hirsch (Bedford), N. R. Knowles (Belfast), and Miss M. P. Scarr (Bromley), was on "Aspects of Food Preservation". In introducing the subject Mr. Hawley described the origin and some of the earlier methods of food preservation and then, having outlined the principles required, gave some of the modern chemical, physical and biological methods in use. Dr. Ingram discussed the possibility of sterilization by high-frequency voltage fields using a voltage gradient of $1,000 \mathrm{~V} \cdot / \mathrm{cm}$. Heating during treatment is a major problem, and special precautions and apparatus have to be used to keep the test material cool. He described various types of apparatus and pulsation treatments employed experimentally, and 